\title{
THE EFFECT OF LONG-TERM THERAPEUTIC BATH OF MALACHITE GREEN ON COMMON CARP (CYPRINUS CARPIO L.)
}

\section{Z. SVOBODOVÁ ${ }^{1.2}$, L. GROCH ${ }^{2}$, M. FLAJŠHANS ${ }^{1}$, B. VYKUSOVÁ', J. MÁCHOVÁ ${ }^{1}$}

${ }^{1}$ Research Institute of Fish Culture and Hydrobiology, University of South Bohemia, Vodňany, Czech Republic 2 Veterinary and Pharmaceutical University, Brno, Czech Republic

Received April 8, 1997

Accepted June 17, 1997

\begin{abstract}
Svobodová Z., L. Groch, M. Flajšhans, B. Vykusová, J. Máchová: The Effect of Long-term Therapeutic Bath of Malachite Green on Common Carp (Cyprinus carpio L.). Acta vet. Brno 1997, 66: 111-117.

The aim of this paper was to determine acute toxicity of malachite green of the Vert Malachite J3E SA Crystaux type for common carp and to evaluate the effect of a 6-day therapeutic bath in 0.5 mg. $1^{-1}$ concentration of this pharmaceutical on values of selected haematological indicators including micronuclei test, as well as on histological composition of tissues of one- to two-year-old carp. The $48 \mathrm{hLC} 50$ value of the malachite green tested was $0.84 \mathrm{mg} \cdot \mathrm{l}^{-1}$. After the 6-day bath, changes in red blood picture [decrease in haematocrit value - PCV $(\mathrm{P}<0.001)$, decrease in mean corpuscular volume - MCV $(\mathrm{P}<0.05)$ and increase in mean corpuscular haemoglobin concentration - $\mathrm{MCHC}(\mathrm{P}<0.01)]$ as well as in white blood picture /decrease in both relative and absolute monocyte count $(\mathrm{P}<0.05$ and $\mathrm{P}<0.01)$, respectively/ were recorded in treated fish $(\mathrm{n}=30)$ compared to the control group $(n=29)$. Other indices of red and white blood picture in these fish did not differ from the control group. A decrease in total protein concentration (TP, $\mathrm{P}<0.01$ ) in blood plasma was found in fish treated with malachite green. By means of a micronuclei test, no effect of long-term bath in malachite green on increase of their frequency in erythrocytes was proved. Histological examination revealed mild regressive changes on gills, mild dystrophic changes in parenchymatous tissues and an increased macrophage activity in treated fish. These changes indicate an increased sensitivity of the fish treated with malachite green to hypoxia and impaired proteosynthesis.
\end{abstract}

Acute toxicity, haematology, micronuclei test, histopathological changes

Malachite green is still one of the mostly used preparations for inhibition of protozoal ectoparasitoses and mycoses of fish and their eggs ( $\mathrm{Nog}$ a 1995), although it has numerous negative side effects. Its current importance even increased, since it was recommended for therapy of a proliferative kidney disease - PKD (Clift on-Hadle y and Alderm an 1987, 1988; Debuf 1991). The negative effects of malachite green are as follows: high acute toxicity for fish (Máchová and S vobodová 1984; Alderman 1985; Obiekezic and Ok a for 1995; Van-Heerden et al. 1995), capacity to accumulate in fish and longterm persistence of residues in tissues (B a uer et al. 1988; A lderm an 1988; Alderman and Clifton-Hadley 1993; Máchová et al. 1996). Furthermore, malachite green is characterized as respiratory poison, teratogen and suspect carcinogen (Meyer and Jorgensen 1983). The negative effect of therapeutic baths in malachite green on haematological indicators and histopathological status of tissues was reported by numerous authors in salmonids (Ross et al. 1985; Pickering and Pottinger 1985; Hlavek and Bulkley 1980; Gerundo et al. 1991) and in silurids (Srivastava et al. 1995).

This paper deals with acute toxicity determination of the malachite green Vert Malachite J3 ESA Crystaux (imported from Italy) and with observation on the effect of a long-term therapeutic bath in this pharmaceutical on haematological indicators and histopathological composition of tissues of common carp. This type of malachite green was succesfully introduced and distributed among Czech fish farms. 


\section{Materials and Methods}

Static acute toxicity test was performed according to the method reported in ON 466807 "Acute Toxicity Test on Fish and Other Aquatic Animals" (1989). Common carp fry (Cyprinus carpio L.) of scaly phenotype with mean body mass $2.42 \pm 0.077 \mathrm{~g}$ and of Fulton's coefficient $2.76 \pm 0.045$ was used. Basic physical and chemical indices of diluting water used in acute toxicity test were as follows: temperature $20 \pm 1.0^{\circ} \mathrm{C}, \mathrm{pH} 7,2-7,6$, acid neutralization capacity $0,47-0,55$ mmol. $1^{-1}$, chemical oxygen demand $\operatorname{COD}_{\mathrm{Mn}} 2,0-2,4 \mathrm{mg} \cdot \mathrm{l}^{-1}, \Sigma \mathrm{Ca}+\mathrm{Mg} 14-15$ $\mathrm{mg} \cdot \mathrm{l}^{-1}, \mathrm{~N}-\mathrm{NH}^{4+} 0,02-0,10 \mathrm{mg} \cdot \mathrm{l}^{-1}$. Oxygen saturation of water did not drop below $60 \%$. Clinical signs of intoxication were observed during the test, followed by pathological and anatomical examination of dead fish. The $48 \mathrm{hLC} 50$ and $48 \mathrm{hLC} 5$ values were determined by probit analysis. Toxic unit (TU) was calculated from the equation:

$\mathrm{TU}=100 / 48 \mathrm{hLC50}(\mathrm{EPA} / 505 / 2-90-001 / 1992)$

Long-term bath of one-and-half-year-old common carp of scaly phenotype in malachite green of the Vert Malachite J3E SA Crystaux type was performed in aquaria of 2001 volume. Bath in concentration of $0.5 \mathrm{mg} . \mathrm{l}^{-1}$ lasted for 6 days. Therapeutic bath was renewed every 24 hours. Water temperature ranged between $10-12^{\circ} \mathrm{C}$ during the bath, values of other physical and chemical indices of water used for the therapeutic bath were the same as stated for the acute toxicity test. Bath was performed in 2 experimental and 2 control aquaria under identical conditions. Stock density was 50 fish per $200 \mathrm{l}$ bath. At termination of the bath, 30 treated and 29 intact fish were examined. Both groups were homogeneous, fish body mass and Fulton's coefficient was practically equal (Table 1).

Blood was sampled by cardiac punction using heparin as anticoagulant. Haematological investigation was carried out according to S vobodová et al. (1986). Erythrocytes of experimental and control fish were used for micronuclei test (MNT) according to Al-S a b ti (1991) with evaluation of frequency of micronuclei in 1000 cells of every specimen. Tissue samples of gills, hepatopancreas, kidney, spleen, heart, brain, skin, muscle and gut were taken for histological examination. Tissues were fixed in $10 \%$ formalin, conventionally processed and stained by haematoxylin and eosin.

Results were processed statistically by means of t-test in Statgraphics v. 5.0 software.

\section{Results}

\section{Acute toxicity of malachite green}

Values of $48 \mathrm{hLC} 50$ and $48 \mathrm{hLC} 5$ were determined as $0.84 \mathrm{mg} . \mathrm{l}^{-1}$ and $0.64 \mathrm{mg} \cdot \mathrm{l}^{-1}$, respectively. Based on these values, malachite green Vert Malachite J3 ESA Crystaux can be classified as strongly poisonous substance for common carp (5th toxicity class according to ON 466807 "Acute Toxicity Test on Fish and Other Aquatic Animals" 1989). The toxic unit of this malachite green is higher than 100 resulting in classification of this pharmaceutical among substances extremely toxic for common carp. The course of fish poisoning with malachite green is very fast. Fish die mainly during the first two hours after initiation of the test. Clinical signs of poisoning are characterized by strong restlessness, fish moving across the bath in an uncoordinated manner, stay in the upper half of the vessel, jump above the water surface and gasp. Loss of balance, total immobility, agony follow, and the fish perish. Pathological and anatomical picture of the poisoning is characterized by increased mucus excretion and greenish colour of body surface. Gills are oedematously intumescent, stained by the preparation. Increased injection of vessels can be observed in the body cavity, often along with green colouration of viscera.

\section{Haematological examination}

Results of haematological examination of both control and experimental carp are given in Table 1. It is evident that there is a negative effect of the therapeutic bath in malachite green on blood picture. A highly significant decrease was found in haematocrit value (PCV; $\mathrm{P}<0.001)$ as well as a significant decrease in mean corpuscular volume (MCV; $\mathrm{P}<0.05)$. On the other hand, mean corpuscular haemoglobin concentration $(\mathrm{MCHC})$ was found increased $(\mathrm{P}<0.01)$.

As far as white blood picture values are concerned (Table 1) no significant differences 
Table 1

Haematological indices of common carp after a 6-day bath in malachite green at the concentration of $0.5 \mathrm{mg.1}^{-1}$

\begin{tabular}{|c|c|c|c|}
\hline Parameter & Unit & $\begin{array}{c}\text { Control group } \\
\mathrm{x} \pm \mathrm{s}_{\mathrm{x}} \\
\mathrm{n}=29\end{array}$ & $\begin{array}{c}\text { Experimental group } \\
\mathrm{y} \pm \mathrm{s}_{\mathrm{x}} \\
\mathrm{n}=30\end{array}$ \\
\hline Fish body mass & $\mathrm{g}$ & $148.3 \pm 6.35$ & $146.5 \pm 4.74$ \\
\hline Fulton's coefficient & & $2.97 \pm 0.06$ & $2.95 \pm 0.05$ \\
\hline Haematocrit (PCV) & $\mathrm{V} / \mathrm{I}$ & $0.27 \pm 0.005$ & $0.24 \pm 0.004^{* * *}$ \\
\hline Erythrocytes (Er) & $\mathrm{T} / \mathrm{I}$ & $1.33 \pm 0.037$ & $1.27 \pm 0.02$ \\
\hline Haemoglobin (Hb) & $\mathrm{g} / \mathrm{I}$ & $53.6 \pm 1.05$ & $54.0 \pm 1.61$ \\
\hline MCV & $\mathrm{f} / \mathrm{I}$ & $206 \pm 4.2$ & $193 \pm 3.3 *$ \\
\hline MCHC & $\mathrm{I} / \mathrm{I}$ & $0,20 \pm 0.003$ & $0.22 \pm 0,008^{* *}$ \\
\hline MCH & $\mathrm{pg}$ & $40.6 \pm 1.00$ & $42.6 \pm 1.32$ \\
\hline Leukokrit (BC) & $\%$ & $1.30 \pm 0.093$ & $1.46 \pm 0.069$ \\
\hline Leukocytes (Leuko) & $\mathrm{G} / \mathrm{I}$ & $49.3 \pm 2.76$ & $46.4 \pm 3.38$ \\
\hline Small lymphocytes & $\%$ & $77.7 \pm 2.70$ & $76.5 \pm 2.49$ \\
\hline Large lymphocytes & $\mathrm{G} / \mathrm{I}$ & $39.5 \pm 2.87$ & $37.3 \pm 3.46$ \\
\hline Neutrophile granulocytes & $\mathrm{G} / \mathrm{I}$ & $0.55 \pm 0.12$ & $0.94 \pm 0.22$ \\
with elongated nucleus & $\mathrm{G} / \mathrm{I}$ & $0.25 \pm 0.043$ & $0.37 \pm 0.087$ \\
\hline Neutrophile granulocytes & $\%$ & $12.7 \pm 2.05$ & $15.4 \pm 1.93$ \\
with segmented nucleus & $\mathrm{G} / \mathrm{I}$ & $5.76 \pm 0.881$ & $5.96 \pm 0.710$ \\
\hline Monocytes & $\%$ & $6.16 \pm 0.79$ & $5.49 \pm 0.58$ \\
\hline TP & $\mathrm{G} / \mathrm{I}$ & $3.07 \pm 0.49$ & $2.33 \pm 0.26$ \\
\hline & $\mathrm{g} / \mathrm{I}$ & $2.83 \pm 0.35$ & $1.87 \pm 0.31^{*}$ \\
\hline & & $1.31 \pm 0.16$ & $0.70 \pm 0.10^{* *}$ \\
\hline
\end{tabular}

* statistically significant $\mathrm{P}<0.05 \quad * *$ statistically significant $\mathrm{P}<0.01 \quad * * *$ statistically significant $\mathrm{P}<0.001$

between the control and experimental fish were detected either in leukocyte count, or in differential leukocyte count. The only exception was a significant decrease in monocyte count either in percentage $(\mathrm{P}<0.05)$, or absolutely $(\mathrm{P}<0.01)$.

Furthermore, a significant difference $(\mathrm{P}<0.01)$ in total protein content $(\mathrm{TP})$ between the control and experimental common carp is evident from Table 1. The effect of the long-term bath in malachite green caused a marked decrease of total protein concentration in blood plasma of common carp.

\section{Micronuclei test (MNT)}

The result of a micronuclei test on erythrocytes of both control and experimental group is given in Table 2. Within both groups of fish, micronuclei were registered in low frequency or they were not registered at all. Hence, no significant difference was found between micronucleic frequency in erythrocytes of experimental and control fish group.

Table 2

Micronuclei test of common carp after a 6-day bath in malachite green

\begin{tabular}{|l|c|c|c|}
\hline Group & $\mathrm{n}$ & $\begin{array}{c}\text { Live body mass }(\mathrm{g}) \\
\mathrm{x} \pm \mathrm{s}_{\mathrm{x}}\end{array}$ & $\begin{array}{c}\text { Micronuclei }\left(\%{ }_{00}\right) \\
\mathrm{x} \pm \mathrm{s}_{\mathrm{x}}\end{array}$ \\
\hline Control & 29 & $148.3 \pm 6.35$ & $1.00 \pm 1.65$ \\
\hline Experimental & 30 & $146.5 \pm 4.74$ & $0.57 \pm 0.94$ \\
\hline
\end{tabular}


Histological examination

After examination of common carp from the long-term bath in malachite green, mild regressive changes were registered on gills on respiratory epithelium folia, consisting of intumescence, vacuolization and desquamation of cells. Capillary ectasia on the folia top was registered in some specimens. Hepatopancreas was found with mild focal dystrophic changes in liver parenchyma, locally with manifestations of hepatocyte regeneration. Mild dystrophic changes in tubuli epithelium, mainly in that of proximal segments was found in kidney. A finding in cardial musculature was characterized by repletion of endocardial macrophages. Venostasis was registered in spleen, some specimens were found with increased activation of melanomacrophage centers. Other tissues (i.e. skin, musculature and gut) were found without any histopathological changes. Tissues of the control group of fish were without any histopathological findings.

\section{Discussion}

The ichthyological and toxicological effect of malachite green has been studied by numerous authors (e.g. Clemens and Sneed 1959; Wilford 1967; R e hulk a 1977; Olah and Farkas 1978; Jeney et al. 1980; Máchová and Svobodová 1984; Aldermann 1985; Obiekezic and Okafor 1995; Van Heerden etal. 1995, and others). In accordance with our results, these authors report a high toxicity of malachite green for fish. Moreover, it is necessary to point out that the toxicity of malachite green is remarkably affected by the quality of diluting water, namely by its $\mathrm{pH}$ and $\mathrm{\Sigma Ca}+\mathrm{Mg}$. $\mathrm{An}$ expressive acute toxicity decrease occurs when suspended organic substances are present in water (Goryczko 1982). When reporting the toxicity of malachite green for fish, it is therefore always necessary to report on quality of water in which the tests was performed.

Changes in red blood picture after a short-term bath in malachite green were reported for rainbow trout by $\mathrm{T}$ a n ck et al. (1995), as well as after a short-term repeated bath for brown trout by $\mathrm{S} \mathrm{u} \mathrm{m}$ a ri et al. (1979). In accordance with our results found in common carp, these authors proved for both trout species an important decrease in haematocrit value. This is followed by a decrease of oxygen transport capacity of blood and by increased sensitivity of fish to hypoxia. Although a significant decrease of haematocrit value occurred in common carp treated by the long-term bath in malachite green, their haemoglobin concentration remained the same and their mean corpuscular haemoglobin concentration was significantly increased. This may be considered a certain compensation for maintenance of blood oxygen transport capacity. Pickering and Pottinger (1985) did not record any decrease in erythrocyte count in brown trout after repeated baths in malachite green. In common carp reported in this study, no significant decrease in erythrocyte count was proved either.

Except for changes in both percentage and absolute monocyte count in common carp studied herein, no significant changes in white blood picture were found compared with the control fish. White blood picture examination of trout after a therapeutic bath in malachite green was described by Pickering and Pot t inger (1985) and Hlavek and B ulk ley (1980). In accordance with our data on common carp, P i c k e ring and P o t t ing e r (1985) did not detect any changes in lymphocyte count in brown trout after repeated baths in malachite green. Although the number of neutrophile granulocytes decreased significantly, this was put in relation to a decrease of ectoparasitic infestation. H lave $\mathrm{k}$ and $\mathrm{B} \mathrm{ulkley}$ (1980) report transient leukopenia, lymphopenia and neutrophilia in response to a short-term bath of rainbow trout in malachite green with values returning to pre-treatment values 1-4 days later. The authors suggest that such changes in white blood picture are rather a result of non-specific stress syndrome than a leukotoxic effect of malachite green. 
Similarly expressive decrease in total protein concentration as reported for common carp herein, is described by S rivastav a et al. (1995) for catfish Heteropneustes fossilis after a long-term bath in malachite green in $0.20 \mathrm{mg} \cdot .^{-1}$ concentration. The decrease of total protein content in blood plasma along with both absolute and relative decrease in monocyte count in common carp studied report on a negative effect of malachite green on proteosynthesis.

Micronuclei test was chosen as a supplemental examination which should inform on genetic deterioration of the examined organism at a cellular level. It is considered either proportional, or slightly underestimating the result of chromosomal aberration analysis (Schmid 1976; Kreppinski and Heddle 1983). It can be therefore used as a first step and in case of a positive result it should be followed by a more distinguishable examination (Flajšh an s 1993a). Micronucleic frequency in control fish, i.e. uncontaminated specimen, is usually reported as 0-6 per mille (Al-S a bti 1986; Al-Sabti 1991; Flajšh an s 1993b).

No difference in frequency of micronuclei between experimental and control fish was found by means of a micronuclei test in this study. It can be therefore stated that this test did not prove any mutagenic effect of a long-term bath in malachite green on common carp genome.

Contrary to our histopathological findings characterized by mild regressive changes on gills, mild dystrophic changes in parenchymatous tissues and macrophage activation, Ge rundo et al. (1991) registered on gills and liver of rainbow trout exposed to repeated bath in malachite green more serious changes causing local dystrophic process, in some cases even followed by necrosis. This is related to increased sensitivity of salmonids to foreign substances, as well as with a more intensive histopathological response to the effect of such substances.

\section{Vliv dlouhodobé léčebné koupele v malachitové zeleni na kapra obecného (Cyprinus carpio L.)}

Cílem práce bylo stanovit akutní toxicitu malachitové zeleně typu Vert Malachite J3E SA Crystaux pro kapra obecného a posoudit vliv 6-ti denní léčebné koupele o koncentraci $0.5 \mathrm{mg} .1^{-1}$ tohoto farmaka na hodnoty vybraných hematologických ukazatelü, včetně testu mikrojader, a na histologickou stavbu tkání kaprů $\mathrm{K}_{1.2}$. Hodnota $48 \mathrm{hLC50}$ testované malachitové zeleně byla $0.84 \mathrm{mg} \cdot \mathrm{l}^{-1}$. Po 6-denní léčebné koupeli byly zjištěny u ošetr̂̌ených ryb $(\mathrm{n}=30)$ ve srovnání s rybami kontrolními $(n=29)$ signifikantni změny v červeném krevním obrazu (snížení hematokritové hodnoty - PCV $/ \mathrm{P}<0.001 /$, snížení objemu erytrocytů - MCV $/ \mathrm{P}<0.05 /$ a zvýšení střední barevné koncentrace MCHC $/ \mathrm{P}<0.01 /$ ) a v bílém krevním obrazu (snižení relativního $/ \mathrm{P}<0.05 /$ a absolutniho $/ \mathrm{P}<0.01 /$ počtu monocytů). Hodnoty ostatních ukazatelủ červeného a bílého krevního obrazu nevykazovaly u ryb po koupeli v malachitové zeleni rozdílné hodnoty ve srovnání s rybami kontrolními. Signifikantní snížení koncentrace celkových bílkovin (TP $/ \mathrm{P}<0.01 /$ ) v krevní plazmě bylo prokázáno u ryb ošetřených malachitovou zelení. Pomocí testu mikrojader (MNT) nebyl prokázán vliv dlouhodobé koupele $\mathrm{v}$ malachitové zeleni na četnost jejich výskytu $\mathrm{v}$ erytrocytech. Histologickým vyšetřením tkání kaprư ošetřených léčebnou koupelí v malachitové zeleni byly zjištěny mírné regresivní změny na žábrách, mírné dystrofické změny v parenchymatózních tkáních a zvy̌šená aktivace makrofágů. Popsané změny svědčí o zvýšené citlivosti ošetrených ryb k hypoxickým stavủm a o poruše proteosyntézy.

\section{Acknowledgement}

This research was supported as Project No. 4013 by the National Agency for Agricultural Research. Ministry of Agriculture of the Czech Republic and as Project No. 511/93/2399 by the Grant Agency of the Czech Republic. The research performed followed the regulations of the Ethical Board of Animal Welfare Protection of the Research Institute of Fish Culture and Hydrobiology. University of South Bohemia at Vodñany.

\section{References}

ALDERMAN, D. J. 1985: Malachite green: a review. J. Fish. Dis. 8:289-298

ALDERMAN, D. J., CLIFTON-HADLEY, R. S. 1993: Malachite green: A pharmacokinetic study of rainbow trout, Oncorhynchus mykiss (Walbaum). J. Fish. Dis. 4:297-311

AL-SABTI. K. 1986: Comparative micronucleated erytrocyte cell induction in three cyprinids by five carcinogenic-mutagenic chemicals. Cytobios 47:147-154

AL-SABTI, K. 1991: Handbook of genotoxic effects and fish chromosomes. J. Stefan Institute, Ljubljana, 221 pp.

BAUER, K., DANGSCHAT, H., KNÖPPLER, H. O.. NEUDEGGER, J. 1988: Aufnahme und Ausscheidung von Malachitgrün bei Regenbogenforellen. Archiv für Lebensmittelhygiene 39, pp. 85-108 
CLEMENS, H.P., SNEED, K.E. 1959: Lethal doses of several commercial chemicals for fingerling channel catfish. U.S. Fish Wild. Serv., Sp. Sci.. Rep. Fish. No. 316, 10 p.

CLIFTON-HADLEY, R. S., ALDERMAN, D. J. 1987: The effects of malachite green upon proliferative kidney disease. J. Fish. Dis. 2:101-107

CLIFTON-HADLEY, R. S., ALDERMAN, D. J. 1988: The malachite green answer to PKD. Fish Farmer. 6: 18-19

DEBUF, Y. 1991: The Veterinary Formulary. London, Pharmaceutical Press.

FLAJŚHANS, M. 1993a: The application of cytogenetic methods for detection of mutagenic effects of aquatic pollutants on fish genome. A review. Bulletin VÚRH, 2:67-70 (in Czech)

FLAJŠHANS, M. 1993b: Detection of mutagenic alterations in fish genome by means of micronuclei test on erythrocytes. In: Proc. 3rd. Ichthyohaematological Conference (Vykusová, B., Svobodová, Z., Máchová, J.. Eds.), RIFCH Vodňany, pp. 19-24.

GERUNDO, N., ALDERMAN, D. J., CLIFTON-HADLEY, R. S., FIEST, S. W. 1991: Pathological effects of repeated doses of malachite green: a preliminary study. J. Fish. Dis. 5:521-532

GORYCZKO, K. 1982: Gdy stosujemy zielen malachitowa. Gosp. ryb. 34, 3:17-18

HLAVEK, R. R., BULKLEY, R. V. 1980: Effects of malachite green on leucocyte abundance in rainbow trout, Salmo gairdneri (Richardson). J. Fish. Biol. 4:431-444

JENEY, G.,JENEY.Z., OLÁH, J. 1980: Susceptibility of sheatfish fry to malachite green. formalin and antibiotics. Aquacultura Hungarica 2:124-130

KREPINSKI, A. B., HEDDLE, J. A. 1983: Micronuclei as a rapid and inexpensive measure of radiation-induced chromosomal aberrations. Radiation-induced chromosome damage in man. New York, N.Y. A.R. Liss., pp. 93-109

MÁCHOVÁ. J.. SVOBODOVÁ. Z. 1984: Evaluation of four of malachite green at to acute toxicity to fish. Práce VÚRH Vodňany. 13: pp. 41-49

MÁCHOVÁ, J., SVOBODOVÁ, Z., SVOBODNIK, J., PIAČKA, V., VYKUSOVÁ, B., KOCOVÁ, A. 1996: Persistence of malachite green in tissues of rainbow trout after a long-term therapeutic bath. Acta vet. Brno 65:151-159

MEYER, F. P.. JORGENSEN, T. A. 1983: Teratological and other effects of malachite green on the development of rainbow trout and rabbits. Trans. Am. Fish. Soc. 112:818-824

NOGA, E. J. 1995: Fish disease - diagnostic and treatment. Mosby St. Louis, 365 p.

OBIEKEZIE, A.. OKAFOR, N. 1995: Toxicity of four commonly used chemotherapeutic compounds to fry of the African catfish. Clarias gariepinus (Burchell). Aquacult. Res. 6:441-445

OLAH, J., FARKAS, J. 1978: Effects of temperature, pH, antibiotics, formalin and malachite green on the growth and survival of Saprolegnia and Achlya parasitic on fish. Aquaculture 13:273-288

PICKERING, A. D., POTTINGER, T. G. 1985: Acclimation of the brown trout, Salmo trutta L., to the stress of daily exposure to malachite green. Aquaculture 2:144-152

PROST, M., STUDNICKA, M., NIEZGODA, J. 1975: Porównanie toksycznosci blekitu metylenowego i zieleni malachitowej dla narybku pstraga teczowego. Med. Wet. 31:226-229

ROSS, L. G., WARD, K. M. H., ROSS, B. 1985: The effects of formalin, malachite green and suspended solids on the respiratory activity of rainbow trout, Salmo gairdneri Richardson. Aquacult. Fish. Manage. 2:129-138

SCHMID, W. 1976: The micronucleus test for cytogenetic analysis. Hollaender (ed.) Chemical mutagens: principles and methods for their detection. Vol. 4., New York, Plenum Press, pp. 31-53

ŘEHULKA, J. 1977: Použití, snášenlivost a toxicita dlouhodobé koupele v malachitové zeleni B pro podzimní kapří plůdek. Živ. Výr. 22:711-720

SRIVASTAVA, S. J., SINGF, N. D., SRIVASTAVA, A. K. 1995: Acute toxicity of malachite green and its effects on certain blood parameters of a catfish, Heteropneustes fossilis. Aquat. Toxicol. 3:241-247

SUMARI, O., VIRTANEN, H., SOIVIO, A. 1979: Formaliini-, suola-, malakiittivihreäja kaliumpermanganaattihoidon vaikutuksesta taimenen (Salmo trutta $L$.) kasvuum ja kuntoon. Suomen kalatalous 49:1-8

SVOBODOVÁ, Z., PRAVDA, D., PALÁČKOVÁ, J. 1986: Jednotné metody hematologického vyšetřování ryb. Edice metodik VÚRH Vodñany, 22, $34 \mathrm{p}$.

TANCK, M. W. T., HAJEE, C. A. J., OLLING, M., HAAGSMA, N., BOON, J. H. 1995: Negative effect of malachite green on haematocrit of rainbow trout (Oncorhynchus mykiss Walbaum). Bull. Eur. Ass. Fish. Pathol. 4:134-136

VAN-HEERDEN, E., VAN-VUREN, J. H. J., STEYN, G. J. 1995: LC sub(50) determination for malachite green and formalin on rainbow trout (Oncorhynchus mykiss) juveniles. Water S. A., 21: 87-94

WILLFORD, W.A. 1967: Toxicity of 22 therapeutic compounds to six fishes. Invest. Fish. Control, Bur. Sport Fish. Wildlife, Washington, pp. 3-10

ON 466807 Test akutní toxicity na rybách a dalších vodních živočiších. ÚNM Praha, 1989, 31 p.

Address for correspondence:

MVDr. Zdeňka Svobodová, DrSc.

Research Institute of Fish Culture and Hydrobiology

University of South Bohemia, Vodñany

Zátǐ̌i 728/II

38925 Vodñany

Czech Republic

Phone: 420342382402

Fax: 420342382396 